\title{
A Newborn Case of "c" Subgroup Mismatch Presenting with Severe Hemolysis and Anemia
}

\author{
Ağır Hemoliz ve Anemiyle Bașvuran "c" Subgrup Uyușmazlıklı Bir \\ Yenidoğan Olgusu
}

\author{
Ezgi Yangın Ergon, Senem Alkan Özdemir, Rüya Çolak, Kıymet Çelik, Özgür Olukman, \\ Şebnem Çalkavur
}

University of Health Sciences, Dr. Behçet Uz Children's Diseases and Surgery Training and Research Hospital, Department of Neonatology, Izmir, Turkey

\begin{abstract}
Hemolysis and jaundice related to Rh incompatibility in the neonatal period has decreased substantially due to the widespread use of anti-D gammaglobulin in recent years. Nevertheless, the rate of subgroup mismatch in the etiology of hemolytic diseases of the newborn has increased significantly. In this article an 8-day-old newborn infant with "c" subgroup incompatibility and presenting with severe anemia, in whom hemolysis could be controlled with intravenous immunoglobulin infusion and subgroup appropriate blood transfusion, has been presented. Scientific studies have demonstrated that the hemolytic disease of patients who don't have major blood group incompatibility but carry anti-C antibodies can be rather serious. Therefore, subgroup mismatch should always be kept in mind for newborns presenting with severe hemolytic anemia, and transfusion or if necessary exchange transfusion should be provided with subgroup matched blood products.

Keywords: Subgroup mismatch, newborn, hemolytic anemia, intravenous immunoglobulin
\end{abstract}

$0 ̈ Z$

Son yıllarda anti-D gamaglobulin kullanımının yaygınlaşması ile birlikte yenidoğan döneminde Rh uyuşmazlıklarına bağı hemoliz ve sarlık büyük ölçüde azalmışır. Bununla beraber subgrup uyuşmazlıklarının yenidoğanın hemolitik hastalı̆ı etiyolojisindeki oranı önemli ölçüde artmışır. Bu makalede; postnatal 8. gününde, ağır anemiyle seyreden, intravenöz immünoglobulin ve subgrup uygun kan transfüzyonu ile hemolizi kontrol altına alınan bir subgrup "c" uyuşmazlığı olgusu sunulmuştur. Bilimsel çalışmalar, majör kan grubu uyuşmazlığı bulunmayan, ancak anti-C antikorları taşıyan olgularda hemolitik hastalığın oldukça ciddi seyredebildiğini göstermiştir. Bu nedenle şiddetli hemolitik anemi ile kliniğe başvuran yenidoğanlarda her zaman subgrup uyuşmazl|kları akılda bulundurulmalı, subgrup uygun kan ürünleri ile transfüzyonları ve gerekirse kan değişimleri sağlanmalıdır.

Anahtar Kelimeler: Subgrup uyuşmazlığı, yenidoğan, hemolitik anemi, intravenöz immünoglobulin

\section{Introduction}

The formation of antibodies against the erythrocyte antigen in pregnancy is called erythrocyte isoimmunization, and after birth it is called erythrocyte alloimmunization. The perinatal outcome of this process is hemolysis and anemia in the fetus/newborn or hemolysis disease of the fetus/ newborn (1). Neonatal hemolytic disease is caused by the formation of maternal antibodies against fetal erythrocyte antigens and these antibodies causing hemolysis in the

Address for Correspondence/Yazıșma Adresi

Ezgi Yangın Ergon MD, University of Health Sciences, Dr. Behçet Uz Children's Diseases and Surgery Training and Research Hospital, Department of Neonatology, Izmir, Turkey

Phone: +90 5333485645 E-mail: yanginezgi@yahoo.com ORCID ID: orcid.org/0000-0003-0836-7379

Received/Geliş tarihi: 02.06.2016 Accepted/Kabul tarihi:10.09.2016

A brief summary of this case was presented as poster at the $24^{\text {th }}$ National Neonatal Congress.

${ }^{\circ}$ Copyright 2017 by Ege University Faculty of Medicine, Department of Pediatrics and Ege Children's Foundation

The Journal of Pediatric Research, published by Galenos Yayınevi. 
fetus or newborn by passing through the placenta passively. Today with the widespread use of anti-D gammaglobulin, immunohemolytic anemia due to Rh incompatibility, and indirect hyperbilirubinemia have decreased while the rate of subgroup incompatibility in the etiology of newborn hemolytic disease is increasing $(2,3)$.

The most common subgroup incompatibilities are; non-D Rh antigens (c, C, e, E), Kell, Duffy, Kidd and MNS. In the United States of America in 1969, 18.000 prenatal serum for red cell antibodies were screened, and 37.000 were screened in 1996. RhD alloimmunisation causing immunohemolysis in newborns decreased from 16.5 cases per 1000 samples in 1969 to 2.7 per 1000 in 1996 while Kell alloimmunisation increased from 1.6 cases per 1000 in 1969 to 3.2 per 1000 in 1996 (3). Due to subgroup incompatibilities, there may be many clinical findings ranging from subclinical hemolysis to severe hemolysis and blood exchange. The potentiality of the increased antibodies causing severe hemolysis due to these incompatibilities are significantly higher than others in some subgroups (such as "c" incompatibility) (4).

Here, a rare case of severe hemolysis and severe anemia due to " $c$ " subgroup incompatibility is presented.

\section{Case Report}

The Apgar score of the 2850-gr-newborn girl of a twentyfive-year-old healthy mother delivered by normal spontaneous vaginal delivery was 8 at the 1 st minute, and 10 at the $10^{\text {th }}$ minute; and no parental consanguinity was found. In the antenatal period, ultrasonography (USG) follow-ups had been normal and the mother had had vitamin and iron supplements. On the family history, there was an isolated cleft palate in one sibling and the other one was healthy, neither of whom had newborn jaundice and/or phototherapy history. The patient who had no clinical problems in the early neonatal period was hospitalized on the $8^{\text {th }}$ postnatal day due to palpitations, tachycardia and hepatomegaly in the neonatology policlinic where she came for examination. It was found that the body weight was 2650 gr (3-10 percentile), height was $47.5 \mathrm{~cm}$ (10-50 percentile), and the circumference of the head was 33 cm (10 percentile). Vital findings were; heart rate: 190/min; arterial blood pressure: $85 / 44$ (55) $\mathrm{mmHg}$; temperature: 36.7 ${ }^{\circ} \mathrm{C}$; respiratory rate: $66 / \mathrm{min}$; and $\mathrm{SpO}_{2}$ was $98 \%$ (with $5 \mathrm{Lt}$ / min in oxygen support). In the physical examination it was found that the case was tachypneic and the skin color was pale; had cardiac $2 / 6$ systolic murmur, liver was located $3 \mathrm{~cm}$ under the rib, and neonatal reflexes were slightly decreased. In the laboratory tests haemoglobin was found to be $3 \mathrm{~g} /$ $\mathrm{dL}$, hematocrit was $15.5 \%$, mean corpuscular volume 139.5 $\mathrm{fL}$, red cell distribution width $18.8 \%$. Leukocyte count was $100260 / \mathrm{mm}^{3}$, and thrombocyte count was $424000 / \mathrm{mm}^{3}$. In the peripheral blood smear, mature normoblast increase was apparent, and thrombocytes were sufficient and clustered; atypical cells and blast were not observed. Total bilirubin was found to be $6.1 \mathrm{mg} / \mathrm{dL}$, direct bilirubin was $0.8 \mathrm{mg} / \mathrm{dL}$, lactate dehydrogenase was $2030 \mathrm{IU} / \mathrm{L}$, uric acid was $10 \mathrm{mg} / \mathrm{dL}$, and there was no ion imbalance in the patient who had normal liver and kidney function tests. The maternal and infant blood groups showed A Rh (+), direct coombs +4 positive, and the reticulocyte value was found to be significantly increased by $32 \%$, and the peripheral blood smear supported hemolysis. After conducting tests for anemia, erythrocyte suspension transfusion (ERT) was planned. During blood preparation, appropriate mastitue support and inotropic support were provided, and intravenous immunoglobulin (IVIG) was administered at $1 \mathrm{~g} / \mathrm{kg}$ considering severe immunohemolytic anemia. Thyroid hormones and glucose-6phosphate dehydrogenase enzyme levels were found to be normal before transfusion, TORCH and parvo virus serology were negative. Cranial and submucosal USG, which was done to see possible bleeding into closed spaces, was found to be normal. Immune hemolytic anemia was suspected in the infant with +4 positive direct coombs, reticulocytosis, and severe hemolytic findings in the peripheral blood smear. When the etiology of immune hemolysis was examined, there was no AB0, RhD incompatibility between the mother and baby. Antibody screening was performed before transfusion, but antibody detection could not be done due to technical reasons. Because of this, the cause of this severe immunohemolytic anemia could not be detected, and " $c$ " subgroup incompatibility was considered.

Owing to the presence of cardiac insufficiency, the patient was transfused with $10 \mathrm{cc} / \mathrm{kg} /$ dose, with A RhD positive, "c" antigen negative, leucocyte-less ERT. IVIG was administered once more at $1 \mathrm{~g} / \mathrm{kg} 12$ hours after hospitalization because post-transfusion hemoglobin was $6.7 \mathrm{gr} / \mathrm{dL}$, hematocrit was $22.6 \%$, also oxygen requirement continued, and there was tachycardia retention. With the administration of ERT 10 $\mathrm{cc} / \mathrm{kg}$ once again, the hemolysis was controlled, oxygen requirement and tachycardia decreased, inotropic support was gradually reduced and cut. When the patient was stabilized, echocardiography was performed due to the possibility of additional cardiac pathology that could lead to cardiac failure; but no symptoms were detected. In the follow-up, the patient, who had no recurrent hemolysis whose vital signs were stable, who had received total oral nutrition and gained weight, was discharged from hospital on the 18th postnatal day to be followed up in the polyclinic. The case was followed up at regular intervals until the age of 1. During that time, hemolysis did not recur, growth and development were consistent with its age group, pathological anemia did not develop, and early iron supplementation was not needed. For this article the family was informed, written and spoken approvals were taken from the family.

\section{Discussion}

The most common cause of hemolytic anemia and pathological neonatal jaundice is blood group incompatibility, and the etiopathogenesis is based on the formation of antibodies in the mother against the antigens in the erythrocytes of the newborn. Antibodies causing hemolysis 
of the fetus and newborn erythrocytes are most commonly seen in $\mathrm{ABO}$ and RhD incompatibilities. Although approximately $15 \%$ of live births present this risk, the syndromes appear only in $0.3 \%$ to $2.2 \%$ of infants (5).

The most common subgroup incompatibilites are; Kell, Duffy, Kidd and MNS, which are the non-D Rh antigens (c, C, e, E) (3). In a study conducted among 452 women with a positive indirect Coombs test, antibody incidence of fetal haemolytic disease was as follows: anti-D 18.4\%, anti-E 14\%, anti-C 5.8\%, anti-C 4.7\%, anti-Kell 22\%, anti-MNS $4.7 \%$, Duffy $5.4 \%$, and Jka $1.5 \%$ (6). Another study carried out with 507 antibody-positive women in Poland, showed that 106 of them (21\%) had non-anti-D antibodies; and in 46 of these (\%43) Rh subgroups (C, C, E, e, G, Rh17); in 35 (\%33) of them $K$ and $k$; and in the other 25 (\%24) other antigens were detected. Nowadays, all women are screened for blood group and antibody presence on the first prenatal examination in order to be protected from $\mathrm{Rh}$ alloimmunisation. Hemolytic disease of the newborn due to maternal isoimmunisation is gradually decreasing with the application of anti-D gammaglobulin prophylactically on the $28^{\text {th }}$ gestational week to all Rh-negative women with no alloimmunization findings; however, there is an increase in the frequency of isoimmunization due to subgroups including anti-E, anti-Kell and anti-C (7).

The pathophysiology of isoimmunisation in subgroup incompatibility is similar to $\mathrm{Rh}$ incompatibility; the clinic of the disease may vary widely, ranging from the subclinical hemolysis to severe hemolysis, deep anemia, and hyperbilirubinemia, which requires blood exchange. Among subgroup incompatibilities, anti-c may cause more severe hemolytic disease. The highest levels of bilirubin have been reported in cases with hemolytic disease due to anti-c antibody $(8,9)$. In the study in which Dajak et al. (10) studied 44 newborns with hemolytic disease due to subgroup incompatibility, a severe hemolysis was observed in 14 of them, and it was found that hemolytic disease was more severe in 8 who were anti-c antibody positive. In our case, "c" antigen was positive and severe hemolysis had developed, and this patient applied to our hospital with cardiac insufficiency due to hemolysis.

In the immunohemolytic anemia of the newborn; intravascular hemolysis findings such as indirect hyperbilirubinemia, shortened erythrocyte sedimentation, increased urobilinogen excretion, hemoglobinemia, hemoglobinuria, hemosiderinuria, methemalbuminemia due to erythrocyte destruction; and reticulocytosis, macrocytosis, normoblastemia, leukocytosis and thrombocytosis due to increased erythropoiesis may ocur in the peripheric blood (11). There is erythroid hyperplasia in the bone marrow (11). In our case, significant leukocytosis and mature normoblast increase was seen in the peripheral blood smear.

In the studies carried out, direct coombs test was found to be positive in $33 \%$ of the cases in which subgroup disagreement was detected. In cases with hemolytic anemia, the direct coombs test is not always positive or negative, which does not mean there is no incompatibility. This is thought to be due to the poor antigenic properties of subgroup antigens (4). In our case, the direct coombs test was positive +4 , which supports severe hemolysis.

In hemolytic diseases due to subgroup incompatibilities, an early high-dose of IVIG, which is thought to demonstrate its effect by altering the expression and function of reticuloendothelial system Fc receptors, and interacting with complex activation, can prevent hemolysis (9). As stated in the Turkish Neonatology Association Jaundice Guide, IVIG can be used in the presence of bilirubin levels close to the blood exchange limit in infants with immunohistochemistryindirect hyperbilirubinemia such as Coombs $(+)$ ABO or Rh incompatibility, and subgroup incompatibility. According to the guidelines of the American Academy of Pediatrics, IVIG is given to babies with elevated serum bilirubin levels despite intensive phototherapy, bilirubin levels close to the blood exchange limit, total bilirubin levels at the blood exchange limit at a dose of 0.5 to $1.0 \mathrm{~g} / \mathrm{kg}$ every 2 hours to be repeated after 12 hours if necessary. However, in a newly published meta-analysis of $463 \mathrm{Rh}$ and $350 \mathrm{AB} 0$ incompatibility cases in 2014 , it was reported that the use of IVIG did not reduce the need for blood exchange in neither Rh nor AB0 incompatibility (12). Although there are conflicting publications on the use of IVIG in the hemolytic disease of the newborn, IVIG was administered at a dose of $1 \mathrm{gr} / \mathrm{kg}$ every 12 hours to our case due to detected anemia requiring transfusion, and clinical benefit was obtained in halting hemolysis.

In some countries, despite the low frequency, non-antiD-erythrocyte alloimmunisation screening is recommended for gestation because of severe hemolytic disease due to subgroup incompatibility whereas in some others, these screenings are not recommended $(13,14)$. In our country, anti-D administration in pregnancy for $R$ h incompatibility is adopted as a health policy but screening for subgroup incompatibility in pregnancy is not on the agenda yet (15).

As a result, subgroup incompatibilities should be kept in mind in cases of severe hemolysis as hemolytic disease can be quite severe in cases with subgroup " $c$ " incompatibility even if no major blood group incompatibility is detected in the studies performed; and if blood exchange is required, transfusion and/or blood exchange with the appropriate subgroup of blood should be performed.

\section{Ethics}

Informed Consent: Consent form was filled out by the parent's of the patient.

Peer-review: Externally peer-reviewed.

\section{Authorship Contributions}

Surgical and Medical Practices: E.Y.E., Concept: Ö.O., Design: Ş.Ç., Data Collection or Processing: E.Y.E., S.A.Ö., Analysis or Interpretation: K.Ç., Literature Search: R.Ç., E.Y.E., Writing: E.Y.E.

Conflict of Interest: No conflict of interest was declared by the authors. 
Financial Disclosure: The authors declared that this study received no financial support.

\section{References}

1. Moise Kenneth J. Hemolytic disease of the fetus and newborn. Creasy and Resnik's Maternal - Fetal Medicine, Principles and Practice, 2014;558-68.

2. Zipursky A, Bowman JM. Isoimmune hemolytic diseases. In: Nathan DG, Oski FA (eds). Hematology of Infancy and Childhood, 4th ed. Philadelphia, WB Saunders C, 1993;4473.

3. Moise KJ. Fetal anemia due to non-Rhesus-D red-cell alloimmunization. Semin Fetal Neonatal Med 2008;13:20714.

4. Özkaya H, Bahar A, Özkan A, Kandemir F, Göçmenl, Mete Z. Neonatal Period anemia with symptoms that minor blood group (anti-C, anti-E) nonconformity connected Hemolytic Disease. Turk Pediatri Ars 2000;35:30-5.

5. Rath ME, Smits-Wintjens VE, Walther FJ, Lopriore E. Hematological morbidity and management in neonates with hemolytic disease due to red cell alloimmunization. Early Hum Dev 2011;87:583-8.

6. Geifman-Holtzman O, Wojtowycz M, Kosmas E, Artal R. Female alloimmunization with antibodies known to cause hemolytic disease. Obstet Gynecol 1997;89:272-5.

7. Farnault L, Garcia-Meric P, Cortey A, Arnaud F. Fetomaternal anti-RH3, -4 (anti-E and anti-c) rhesus isoimmunization: a case report. Arch Pediatr 2011;18:176-82.

8. Van Dijk BA, Hirasing RA, Overbeeke MA. Hemolytic disease of the newborn and irregular blood group antibodies in the Netherlands: prevalence and morbidity. Ned Tijdschr Geneeskd 1999;143:1465-9.
9. Kubo S, Ariga T, Tsuneta H, Ishii T. Can high-dose immunoglobulin therapy be indicated in neonatal rhesus haemolysis? A successful case of haemolytic disease due to rhesus $(c+E)$ incompatibility. Eur $J$ Pediatr 1991;150:507-8.

10. Dajak S, Culic S, Stefanovic V, Lukacevic J. Relationship between previous maternal transfusions and haemolytic disease of the foetus and newborn mediated by non-RhD antibodies. Blood Transfus 2013;11:528-32.

11. Gökçe IK, Güzoğlu N, Öncel MY, Çalışçı E, Canpolat FE, Dilmen U. A Hemolytic Disease due to Minor Blood Group (Anti-C and Anti-E) Incompatibility Leading to Symptomatic Anemia in the Neonatal Period. Turkish Journal of Pediatric Disease 2014;1:32-4.

12. Louis D, More K, Oberoi S, Shah PS. Intravenous immunoglobulin in isoimmune haemolytic disease of newborn: an updated systematic review and meta-analysis. Arch Dis Child Fetal Neonatal Ed 2014;99:325-31.

13. Thakral B, Agrawal SK, Dhawan HK, Saluja K, Dutta S, Marwaha N. First report from India of haemolytic disease of newborn by anti-c and anti-E in Rh (D) positive mothers. Hematology 2007;12:377-80.

14. Wu KH, Chu SL, Chang JG, Shih MC, Peng CT. Haemolytic disease of the newborn due to maternal irregular antibodies in the Chinese population in Taiwan. Transfus Med 2003;13:311-4.

15. Orgun A, Çalkavur Ş, Olukman Ö, et al. Role of minor erythrocyte antigens in alloimmunization during indirect hyperbilirubinemia. Turk Pediatri Ars 2013;48:23-9. 